\title{
Virulence Test of Some Phytophthora Megakarya Isolates on Cocoa (Theobroma Cacao L.) Hybrid Pods
}

\author{
Pierre Effa Onomo ${ }^{1,2^{*}}$,Jude Manga Ndjaga ${ }^{1,3}$, Martine Louise ${ }^{1}$ Ondobo, \\ Jules Christian Djoko Kouam ${ }^{1,3}$ and Pierre FrançoisDjocgoue ${ }^{1,3}$ \\ ${ }^{1}$ Laboratory of Plant physiology, Department of Biological Sciences, Higher Teacher's Training College, P.O. \\ Box 47, Yaounde, Cameroon \\ ${ }^{2}$ Department of Biochemistry, Faculty of Science, P.O. Box 812, Yaounde, Cameroon \\ ${ }^{3}$ Department of Plant Biology, Faculty of Science, P.O. Box 812, Yaounde, Cameroon
}

\begin{abstract}
Phytophthora megakarya is an Oomycete which has a negative impact on Cameroon cocoa production. An assessment of the level of virulence of different isolates of P. megakarya in mono or coinfection was performed on some hybrids of cocoa (Theobroma cacao L.) obtained from reciprocal crosses. The isolates tested on eight cocoa hybrids obtained by hand pollinisation were Bakoa, Le4 and Lebdi. Contents of soluble amino acids, sugars, polyphenols and proline were determined using standard methods in mono or coinfected cocoa pods. This study revealed that, the development of the necrotic area in the cortex of cocoa pods was genotype-dependent and isolate-dependent after infection. For this reason, the classification in terms of virulence of isolates was the following: Lebdi $<$ Le4<Bakoa. However, SNK $413 \times$ T 79/501 and T 79/501 $\times$ SNK 413 hybrids were the most tolerant while UPA $134 \times$ ICS 40 and T 79/467 $\times$ SNK 13 hybrids proved to be the most sensitive to threeP. megakarya isolates. Bakoa + Le4 combination was the most aggressive among the other combinations. Groupings of samples were observed using principal component analysis (PCA) and hierarchical cluster analysis. Significant and negative correlations were found between necrosis and three biochemical metabolites (total polyphenols, soluble sugars, Proline andsolubleamino acids) in cocoa hybrids suggesting that these metabolites could be considered as markers of resistance in T. cacao/P. megakarya interactions.
\end{abstract}

Keywords: Biochemical metabolites, coinfection, cortex, markers of resistance, monoinfection, necrosis.

\section{Introduction}

Cocoa is a tropical perennial plant native to the Amazon basin and this area also corresponds to its center of diversity [1]. Cocoa farming is an economic activity of several tropical countries. Africa is today the leading producer of cocoa with about $73.7 \%$ of world production.Five countries stand out for their active involvement in cocoa farming especially Côte d'Ivoire (40.7\%), Ghana (20.2\%), Indonesia (7.2\%), Cameroon $(5.5 \%)$ and Ecuador (5\%) [2].

However, cocoa farming is facing many inconveniences, the most important are: ageing plantations and the high sensitivity of plant material to parasitic pressures [3]. The black pod disease (Bpd) is one of the most prevalent diseases in the genus Theobroma. The emergence of P. megakarya has had dramatic social and economic consequences in cocoa producing countries in West and Central Africa, clearly demonstrating the scale of damage that it may cause in case it spreads into other cocoa producing regions.It is caused by a fungus Phytophthora spp. belonging to the class Oomycetes. This fungus exists in several species [4], but in Cameroon, the predominance of the P. megakarya species has been noticed [5]. It causes damages that can reduce the production by 50 to $80 \%$ [6] and losses in fields up to $100 \%$ if no action of protection is taken [7].

To counter this disease, several control methods are envisaged.The first approach is chemical control, based on the use of fungicides [8][9]. Although effective, this technique is expensive, polluting, binding and not economically viable. Currently there are alternatives and / or additional chemical control methods such as genetic control that involves obtaining tolerant hybrids to this disease [10]. For Bpd resistance, there have been several tests based on leaf inoculation [11][12] and detached pod inoculation [13][14. In Cameroon, several studies were recently carried out to evaluate the resistance of the local and introduced cocoa germplasm. Clonal and progeny material were assessed using leaf disc [15][16] and pod tests [13].

It is in this context that the overall objective of our study was to evaluate, using laboratory testing, the virulence of three isolates of $P$. megakarya in some $T$. cacao hybrids. Quantitativecomparisons of polyphenols, soluble sugars, proline and amino acids contents in mono or coinfected cocoa podswere also investigated. 


\section{Cocoa plant material}

\section{Materials And Methods}

The experimental material used included eight hybrids cocoa pods in experimental farms of SODECAO (Cameroon Cocoa Development Corporation) station in Mengang, Cameroon (Table 1). A total of 120 hybrids were obtained from crossing using hand-pollination techniques [17]. The healthy pods about 3months old were harvested, washed thoroughly with sterile distilled water and then with ethanol $70 \%$. Cocoa genotypes (hybrids) were tested by inoculating whole detached pods with $100 \mu \mathrm{L}$ inoculum (concentrationof 2.5 $\mathrm{x} 10^{4}$ zoospores $\left.\mathrm{mL}^{-1}\right)$ in this trial.

\section{P. megakarya (Oomycete isolates) and cocoa pod inoculation}

Three isolates of P. megakarya (Bakoa, Lebdi and Le4) were obtained from the Biotechnology Centre of the University of Yaounde I, Cameroon. For zoospore production, the isolates were cultured on V8 medium (20\% V8, 0.3\% $\mathrm{Ca}_{2} \mathrm{CO}_{3}, 1.5 \%$ agar-agar and $1000 \mathrm{~mL}$ distilled water) and incubated in the dark at $25 \pm 2{ }^{\circ} \mathrm{C}$. $P$. megakaryasporangia were induced to liberate zoospores by adding sterile distilled water at $4{ }^{\circ} \mathrm{C}$ at room temperature for 1 hour. The zoospore concentration was then adjusted to $2.5 \times 10^{4}$ zoospores per milliliter with a MALASSEZ hemocytometer.

Two conditions were tested: (i) monoinfection (single isolate treatment: Bakoa, Lebdi and Le4) and (ii) coinfection (combination of isolate treatment: Bakoa + Lebdi, Bakoa + Le4 and Lebdi + Le4). For each treatment, pods were inoculated by depositing $100 \mu \mathrm{L}$ of zoospore suspensions into the cortex of pods after wounding. When two isolates were combined, $50 \mu \mathrm{L}$ zoospore $/ \mathrm{mL}$ of each suspension were added to obtain 100 $\mu \mathrm{L}$ of zoospores $/ \mathrm{ml}$ of total solution. One hour after penetration of zoospore suspension, each scarification was then covered with cotton wool soaked in sterile distilled water. Inoculated pods were put into trays and incubated at $25-26^{\circ} \mathrm{C}$ in a dark and humid $(60 \%)$ room.

\section{Evaluation of disease}

The measurement of necrotic lesion size was done 2, 4 and 6 days after inoculation. The diameters of the more or less circular necrotic spots were measured and the surface calculated using [10]formula:

Where: S: necrotic area $\left(\mathrm{cm}^{2}\right)$;

$$
S=D \times d \times \pi
$$

D: necrotic diameter $(\mathrm{cm})$;

d: small diameter $(\mathrm{cm})$.

\section{Total phenolic compound contents}

Total phenolic content was determined following the method of [18]. A sample (50 $\mathrm{mg})$ was extracted with $1 \mathrm{ml}$ of $70 \%$ aqueous ethanol at room temperature. The mixture was centrifuged at $1000 \mathrm{~g}$ for $15 \mathrm{~min}$. The supernatant $(200 \mu \mathrm{l})$ was mixed with $1.5 \mathrm{ml}$ of Folin-Ciocalteu reagent, and allowed to stand at room temperature for $5 \mathrm{~min}$; then $1.5 \mathrm{ml}$ of sodium bicarbonate solution $(0.566 \mathrm{M})$ was added to the mixture. After 60 $\mathrm{min}$, absorbance was read at $725 \mathrm{~nm}$. Results were expressed as gallic acid equivalents. The concentration used was in a range between 0.02 and $0.1 \mathrm{mg} / \mathrm{ml}$.

\section{Total soluble amino acid and total soluble sugar contents}

Amino acid contents were determined by the ninhydrine method [19] with slight modifications. The incubation mixture containing $100 \mathrm{~mL}$ of the ethanol extract, $1 \mathrm{~mL}$ of $80 \%$ ethanol, $1 \mathrm{~mL}$ of $0.2 \mathrm{M}$ citrate buffer (pH 5), and $2 \mathrm{~mL}$ of acetonicninhydrinsolution (1\% ninhydrin and $0.006 \% \mathrm{KCN}$ in acetone) was incubated for $15 \mathrm{~min}$ at $100^{\circ} \mathrm{C}$. The mixture was cooled for 5 min under tap water before adding $8 \mathrm{~mL}$ of distilled water. The absorbance of the purple product was recorded at $570 \mathrm{~nm}$ (Hitachi spectrometer U-200). Glycine equivalents were calculated from a standard curve obtained with pure analytical grade glycine.

For carbohydrate determination, proteins were removed from the ethanolic extract after treatment with basic lead acetate. The carbohydrate extracts were then determined by the anthronmethod: one $\mathrm{mL}$ of the extract was incubated in $5 \mathrm{~mL}$ of anthronsolution $(0.12 \mathrm{~g}$ anthron in $100 \mathrm{~mL} 6.5 \mathrm{M} \mathrm{H} 2 \mathrm{SO} 4)$ at $90^{\circ} \mathrm{C}$ for $10 \mathrm{~min}$. The absorbance of the green product was measured at $630 \mathrm{~nm}$. Results were expressed in $\mu \mathrm{g}$ eq. glucose by reference to the standard.

\section{Proline contents}

Proline contents were determined spectrophotometrically [20]. Acid-ninhydrin was prepared by heating $0.7 \mathrm{~g}$ ninhydrin in $15 \mathrm{~mL}$ glacial acetic acid and $10 \mathrm{~mL} 6 \mathrm{M}$ phosphoric acid, with agitation till dissolution and stored at $4{ }^{\circ} \mathrm{C}$. Approximately $0.3 \mathrm{mg}$ of plant material was homogenised in $8 \mathrm{~mL}$ of $3 \%$ aqueous sulfosalicylic acid and the homogenate filtered through Whatman No2 filter paper. Two $\mathrm{mL}$ of filtrate was reacted with $2 \mathrm{~mL}$ acid-ninhydrin and $1.5 \mathrm{~mL}$ of glacial acetic acid in a test tube for 1 hour at $100^{\circ} \mathrm{C}$, and the 
Virulence Test Of Some Phytophthora Megakarya Isolates On Cocoa (Theobroma Cacao L.)...

reaction terminated in an ice bath. The reaction mixture was extracted with $4 \mathrm{~mL}$ toluene, mixed vigorously with a test tube stirrer for $20 \mathrm{sec}$. The chromophore containing toluene dissolved in the aqueous phase, warmed to room temperature and the absorbance read at $520 \mathrm{~nm}$ using toluene as a blank. The proline concentration was determined from a standard curve and calculated on a fresh weight basis as follows: [ $\mu \mathrm{g}$ proline $/ \mathrm{mL} \times \mathrm{mL}$ toluene $) / 115.5 \mu \mathrm{g} / \mu \mathrm{mole}] /[(\mathrm{g}$ sample $) / 5]=\mu$ moles proline $/ \mathrm{g}$ of fresh weight material.

\section{Statistical analysis}

Data obtained was analysed using SPSS (version 20.0 for windows) to perform analysis of variance (ANOVA). The significance of differences was determined by Tukey's multiple comparison technique. Principal component analysis (PCA) andHierarchical classification of necrotic area were performed with SPAD 5.5 software package.

\section{Disease severity (monoinfection)}

\section{Results}

Reactions of $T$. cacao against $P$. megakaryatook place under controlled conditions. The study showed significant differences $(\mathrm{p}<0.05)$ in the development of necrotic area in the cortex of cocoa pods after infection with $2.5 \times 10^{4}$ zoospores $\mathrm{mL}^{-1}$ of $P$. megakarya isolateon days 2,4 and 6 (Table 2-4).

After infection of $P$. megakarya-Bakoa isolate, eight cocoa genotypes recorded a variation of necrotic lesion size between 5.51 (day 2) and $83.22 \mathrm{~cm}^{2}$ (day 6).

After infection of $P$. megakarya-Lebdi isolate, the lowest necrotic lesion size was observed in thepodofSNK413×T79/501 and T79/501 $\times$ SNK 413 genotypes on days 2, 4 and 6 (Table 3). Contrariwise, the greatest necrotic surface area was recorded in the UPA 134× ICS 40 genotypes at day 2, 4 and 6 following infection, and a significant difference was observed among the other genotypes $(\mathrm{p}<0.01)$ (Table 3$)$.

On day 2 following infection of $P$. megakarya-Le4isolate, the highest necrotic area was recorded in the T $79 / 467 \times$ SNK 13 genotype $\left(9.01 \pm 0.60 \mathrm{~cm}^{2}\right)(\mathrm{p}<0.05)$. Likewise, this hybrid also showed the greatest necrotic surface on days 4 and 6 after treatment (Table 4$)$.

\section{Principal component analysis (PCA) and Hierarchical cluster}

Principal Component Analysis (PCA) shows the 8 pods genotypes distributed according to their tolerance levels to 3-isolates of P. megakarya. The first two components contributed to explain $88.26 \%$ of variability of the necrotic lesion size (Figure 1). The genotype UPA $134 \times$ ICS 40 is showed great sensibility to $P$. megakarya-Bakoa and Lebdi isolates, and this is why Axis 1 clearly separates it from the other genotypes (Figure 1). However, only the genotype T 79/467 x SNK 13 recorded the highest necrotic lesion size after infection of $P$. megakarya-Le4isolate.

Dendrogram, at $95 \%$ similarity, is divided into 5 clusters according to tolerance and susceptibility to the three isolates(Figure 2). Genotypes T 79/476 $\times$ SNK 13 and UPA 134 x ICS 40 were grouped in cluster 1 and cluster 2 respectively, which is composed of susceptible genotypes. These genotypes recorded high necrotic surfaces and are characterized as susceptible to the three pathogens 6 days after inoculation. The third cluster constituted of four genotypes with necrotic surfaces less significant (intermediate tolerance). Clusters 4 and 5 contained genotypes (T 79 / $501 \times$ SNK413 and SNK 413 x T 79 / 501) with highest tolerance to the three isolates. In order to study the coinfection effect of $P$. megakarya isolates, the most susceptible $(\mathrm{T} 79 / 476 \times \mathrm{SNK}$ 13) and the most tolerant (SNK $413 \times \mathrm{T}$ 79/501) hybrid to $P$. megakarya isolates were taking into account.

\section{Attitude of coinfection}

These two cocoa genotypes were infected at different treatment conditions [monoinfection and coinfection (Bakoa+Lebdi, Bakoa+Le4 and Lebdi+Le4)] and necrotic surfaces were obtained on days 2, 4 and 6 . The differences in the necrotic area in the two cocoa genotypes were significant $(\mathrm{p}<0.01)$ (Figure 3 ).

The monoinfection showed the increasing level of virulence isolates of $P$. megakarya studied. To this effect, the combination of the isolates was carried out and the P. megakarya-Bakoa+Le4 isolates were observed for their high aggressiveness on days 2 and 4in tolerant genotype (SNK 413 x T 79/501).But, in the same genotype, $P$. megakarya-Bakoa+Lebdi isolates recorded the highest necrotic area on day 6. Also, on day 6, it was observed that coinfection was more virulent than all three mono infections(Figure 3A).

When the necrotic area on the cortex of cocoa pod $(\mathrm{T} 79 / 476 \times$ SNK 13$)$ infected withP. megakarya isolates (monoinfection and coinfection) was observed, the highest necrotic area was caused by the Bakoa isolate (monoinfection) and the Bakoa+Lebdi isolate (coinfection) on day 2 ( $\mathrm{p}<0.01)$ (Figure 3B). On day 4 and 6 after infection, the genotype T79/476 $\times$ SNK 13 was more susceptible toBakoa isolate.However, the coinfection (Bakoa+Lebdi) yielded a higher necrotic area of $39.97 \%, 443.33 \%$ and $431.14 \%(p<0.01)$ than the various monoinfections of Bakoa, Lebdi and Le4 respectively (Figure 3B). Likewise, the difference in necrotic 
area among Bakoa+Lebdi, Bakoa+Le4 and Lebdi + Le4 combinations was significant $(\mathrm{p}<0.01)$, and the highest virulence was observed in the Bakoa+Lebdiisolate (Figure 3B).

Biochemical metabolites such as total polyphenols, soluble sugars, soluble amino acids and proline were evaluated in the most tolerant and the most susceptible cocoa hybrids obtained in this study (Figure 4). Results showed that SNK413 x T79/501 tolerant hybrid exhibited higher metabolite contents than the susceptible one, in all treatments.

For total polyphenols (TPP), pods infected with P. megakarya-Lebdi isolate recorded the highest amount of TPP in the two hybrids. These values are 10.3 and $7.8 \mathrm{mg} . \mathrm{g}-1 \mathrm{FW}$ for the tolerant and susceptible hybrids respectively. For SNK413 x T79/501 tolerant hybrid, pods coinfected by P. megakarya-Lebdi+Le4 isolates displayed high amounts of TPP. This observation was also made in pods coinfected with $P$. megakaryaLebdi +Le4and with P. megakarya-Bakoa +Le4 in T79/467 x SNK13 susceptible clone (Figure 4A).

Contrary to TPP, cocoa pods infected with P. megakarya-Bakoa + Lebdi isolates recorded the highest amount $(52.5 \mathrm{mg}$.g-1 FW) of soluble sugars both in tolerant and susceptible ones. The two other coinfections displayed lower sugar contents in T79/467 x SNK13 hybrid (Figure 4B).

The stress-related amino acid (proline) was mostly present in pods of tolerant hybrid in all treatments. However, Lebdimonoinfection and Lebdi + Le4 coinfection yielded more proline content than other treatments in SNK413 x T79/501 tolerant hybrids (Figure 4C) with $248 \mathrm{mg} \cdot \mathrm{g}^{-1} \mathrm{FW}$ for Lebdimonoinfection and $235 \mathrm{mg} . \mathrm{g}^{-1}$ FW for Lebdi + Le4 coinfection.

The amino acid contents varied from 4-7.2mg. $\mathrm{g}^{-1} \mathrm{FW}$. Here, the effect of Lebdi and Le4monoinfection is accompanied by the increase of soluble amino acid contents in the two cocoa hybrids. Lebdi + Le 4 coinfection also gave high levels $\left(7 \mathrm{mg} . \mathrm{g}^{-1} \mathrm{FW}\right)$ of soluble amino acid contents in the tolerant clone (Figure 4D).

Except for soluble sugars where Bakoa + Lebdi coinfection was characterized by an increase of about $25 \%$ of this metabolite, the two other coinfections on cocoa pods yielded lower contents of other metabolites compared to monoinfection.

Spearman's correlations between parameters studied (Table 5) showed that there is a significant and negative correlation between necrosis and three biochemical metabolites (TPP, Proline and soluble amino acids) in T79/467 x SNK13 susceptible hybrid. Contrary to these three metabolites, soluble sugars displayed a significant positive correlation with necrosis and this correlation is more accentuated in tolerant hybrid ( $\mathrm{p}<$ $0.01)$ than susceptible ones $(\mathrm{p}<0.05)$.

\section{Discussion}

To assess virulence of three different isolates of P. megakarya, pods of eight hybrids were infected. Data was collected in the second, fourth and sixth day after inoculation. The rate of spread of infection on the genotypes tested was the result of the presence of the pathogenic agent of Bpd of cocoa.

The study showed a considerable genetic variability among the hybrids of cocoa for tolerance to Bpd (Bakoa, Lebdi and Le4). The difference in the necrotic area was significant for all hybrids cocoa $(\mathrm{p}<0.01)$. We observed that SNK 413 x T 79/501 and T 79/501 x SNK 413 were hybrids that displayed the lowest necrotic area to all three isolates, whereas the disease progressed quickly in T 79/467 x SNK 13 and UPA 134 x ICS 40 and these two hybrids were assumed to be susceptible to the Bpd. However, the different responses of cocoa hybrids suggested that there could be an additive and dominant gene effect in the transmission of character [12] [21][22][23]. In the same way, a vast genetic variability for black pod resistance has also been reported in cocoa [9][14][24].In our studies, the levels of tolerance of cocoa could be identified using any Phytophthora species. These findings are in agreement with results reported bysome authors [14][25][26], who showed that the use of the most aggressive species of $P$. megakarya isolates could lead to the identification of useful levels of resistance against the pathogens.

The cluster analysis at $95 \%$ homogeneity performed on all tested variables grouped the varieties into three categories, namely tolerant, intermediate and susceptible, confirming field observations. These experiments clearly showed that two hybrids SNK 413 x T 79/501 and T 79/501 x SNK 413 considered as tolerant recorded lower necrotic lesion sizes following infection with all the P. megakarya isolates (Bakoa, Lebdi and Le4). The findings indicate that the tolerant hybrids could be used in future improvement programs [13][12].

The analysis of the evolution of the necrosis area on two hybrids [SNK 413 x T 79/501 (tolerant) and T $79 / 476 \times$ SNK 13 (susceptible)] showed asignificant difference $(\mathrm{p}<0.05)$ following infection with the three combinations of isolates. The variability of the necrosis area depended on the virulence of the three isolates of $P$. megakarya. Our study showed that, in the same circumstances, the Bakoa isolate was more aggressive than the Ledbi and Le4isolates. Coinfection also indicated that the spread of infection varied with time and was genotype-dependent. In both hybrids SNK $413 \times$ T 79/501 and T 79/467 $\times$ SNK 13, an increase in necrotic surface area was observed from day four to daysix following coinfection (Bakoa+Lebdi). The rapid progression of necrotic area could be interpreted as a synergetic action between 2 pathogens involved in coinfection and the 
Virulence Test Of Some Phytophthora Megakarya Isolates On Cocoa (Theobroma Cacao L.)...

flagging of necrotic area could be due to antagonistic effects of those same pathogens. The results of the present study support the previous results [27] who reported that the coexistence of other fungi with $P$. palmivorain cacao tissues could antagonize the development and virulence of $P$. palmivora. This agrees with findings of several authors[24][28][14][26].However, it has been shown that the host-specific resistance of cacao is often unstable due to the variability of the cacao population [29] while different species of black pod pathogens as well as isolates within the same species have been shown to vary in aggressiveness [30][31].

Quantitative determination of some metabolites revealed that, after P. megakarya-isolates treatment on cocoa pods, the tolerant SNK $413 \times$ T 79/501 cocoa hybrid displayed high level of soluble amino acids, sugars, phenols and proline compared to the susceptible T $79 / 476 \times$ SNK 13 one. In a study assessing relationship between phenolic compounds and resistance to $P$. megakarya using two cocoa families, some authors [32]found that productive and tolerant genotypes displayed high phenols content meanwhile less tolerant and productive ones had a weak content. The role of phenolic compounds in plant defense is well documented [33]. These metabolites accumulate at different levels in infected tissues in response to pathogen attack. For example, some 16 phytoalexins produced by rice (Oryza sativa) in response to pathogen invasionwere listed[34].

Amino acids content increased in leaves of cocoa infected with $P$. megakarya and proline appeared solely during conditions of infection in parental tolerant clone ICS84 suggesting its implication in the defence mechanism of T. cacao against P. megakarya ([35]. In fact, Amino acids might act directly to inhibit fungal development, or indirectly by their implication in the metabolic pathways associated with resistance to diseases [36].After infection of resistant genotypes of some host species, accumulation of certain specific amino acids such as glutamine, histidine, glycine and arginine were observed in tomatoes [37], tyrosine and alanine in wheat and asparagin, glutamic acid, proline, glycine and arginine in citrus [38].

In this study, monoinfection treatment of $P$. megakarya- Lebdi isolate yielded high amounts of phenols, amino acids and proline compared with the other isolates. The negative and significant correlation found between necrosis and three of the four metabolites namely phenols, amino acids and proline suggests that,Lebdi isolate is the less aggressive among the three isolates.

Except for soluble sugars where Bakoa + Lebdi coinfection was characterized by an increase of about $25 \%$ of soluble sugar content, the two other coinfections on cocoa pods yielded lower contents of metabolites compared to monoinfection. This result confirms in part the synergistic effect of $P$. megakarya-isolates observed on disease severity.

\section{Acknowledgments}

The study was supported by the Agence Universitaire de la Francaphonie (AUF) via a grant to Pierre EffaOnomo (Grant No BACGL-2015-35). The authors express gratitude to the Cameroon Cocoa Development Corporation (SODECAO) for the field used.

\section{References}

[1]. Motamayor,J.C., Risterucci,A.M., Lopez,P.A., Ortiz,C.F., Moreno, A., Lanaud,C. (2002). Cacao domestication: the origin of the cultivated by the Mayas.Heredity.89, 380-386.

[2]. Anonymous (2016). Quarterly Bulletin of Cocoa Statistics, 130(1): 3-4.

[3]. Ploetz, R.C. (2007). Cacao diseases: Important threats to chocolate production worldwide. Phytopathology.97: 1634-1639.

[4]. Griffin, M.J. (1976).Cocoa Phytophthoraworshop, Rothamted Experimental Station, England. PANS 23, $107-110$.

[5]. Nyasse, S., Cilas, C., Hérail, C., Blaha, G. (1995). Leaf inoculation as an early screening test for cocoa (Theobroma cacao L.) resistance to Phytophthorablack pod disease.Crop Protection.14,657-663.

[6]. Nyasse, S.(1997). Etude de la diversité de Phytophthora megakaryaet caractérisation de la résistance du cacaoyer (Theobroma cacao L.) à cet agent pathogène. Toulouse,France :Institut National Polytechnique,Ph.DThesis.

[7]. Ndoumbè-Nkeng, M., Cilas, C, Nyemb, E., Nyasse, S., Bieysse, D., Flori, A., Sache, I. (2004). Impact of removing diseased pods on cocoa black pod caused by Phytophthora megakarya and on cocoa production in Cameroon. Crop Protection. 23, $415-424$.

[8]. Ndoumbè-Nkeng, M. (2002). Incidence des facteurs agro-écologiques sur l'épidémiologie de la pourriture brune des fruits du cacaoyer au Cameroun: Contribution à la mise en place d'un modèle d'avertissement agricole. Thèse de Doctorat de l'institut National agronomique (Paris- Grignon).151p

[9]. Nyasse, S., Despréaux, D., Cilas, C.(2002). Validity of a leaf inoculation test to assess the resistance toin cocoa (Theobroma cacao L.) diallelmating design. Euphytica. 123, 395-399.

[10]. Blaha, G., Lotodé, R. (1976). Un critère primordial de sélection du cacaoyer au Cameroun: la résistance à la pourriture brune des cabosses. Variations de réactions à la maladie en liaison avec les données écologiques et l'état physiologique des fruits. Café CacaoThé.20(2), 97-116.

[11]. Efombagn, M.I.B., Bieysse, D., Nyassé, S., Eskes, A.B. (2011). Selection for resistance to Phytophthora pod rot of cocoa (Theobroma cacao L.) in Cameroon: Repeatability and reliability of screening tests and field observations. Crop Protection. 30 , 105-110.

[12]. Manga, N.J., Effa, O.P., Ondobo, M.L., Djoko, K.J.C., Djocgoue, P.F.(2016). Heritability of the tolerance to Phytophthora megakarya Bras.andGrif. ofTheobroma cacao L. in terms of their necrosis length, phenolic contents and activity of enzymes. International Journal of Biosciences.8(5),249-261.

[13]. Djocgoue, P.F., Simo, C., Mbouobda, H.D., Boudjeko, T., Nankeu, D.J., Omokolo, N.D. (2010). Assessment and heritability of productivity and tolerance level to Phytophthora megakarya in two hybrid populations of Theobroma cacao. J. Plant Pathol.92, 607-617 
[14]. Nyadanu, D., Akromah,R., Adomako,B., Kwoseh,C., Lowor,S.T., Dzahini-Obiatey,H., Akrofi,A.Y., Owusu, A.F., Yaw, O.A.,Assuah,M.K. (2013). Biochemical Mechanisms of Resistance to Black Pod Disease in Cocoa (Theobroma cacao L.). American Journal of Biochemistry and Molecular Biology. 3, 20-37.

[15]. Nyassé, S., Efombagn, M.I.B., Bouambi, E., Ndoumbe-Nkeng, M., Eskes, A.B.(2003). Early selection for resistance to Phytophthora megakarya in local and introduced cocoa varieties in Cameroon.Trop. Sci. 43, 96-102.

[16]. Efombagn, M.I.B., Nyassé, S., Sounigo, O., Kolesnikova-Allen, M., Eskes, A.B.(2007). Participatory cocoa Selection in Cameroon: Phytophthora pod rot resistant accessions identified in farmers' field. Crop Protection. 26, 1467-1473.

[17]. Efombagn, M.I.B., Nyassé, S., Sounigo, O., Kolesnikova-Allen, M., Eskes, A.B.(2007). Participatory cocoa Selection in Cameroon: Phytophthora pod rot resistant accessions identified in farmers' field. Crop Protection. 26, 1467-1473.

[18]. Cilas, C.(1991). Estimation of some genetics parameters of different crosses plans of cocoa. Café Cacao Thé.25,3-13.

[19]. Singleton, V.L.,Rossi, J.A.(1965). Colorimetric of total phenolics with phosphomolybdophosphotungsticacid reagents.American Journal of Enology and Viticulture.16, 144-158.

[20]. Yemm, E.W., Cocking, E.C. (1955).The determination of amino acid with ninhydrin. Analyst. 80, 209-213

[21]. Bates, L.S.(1973). Rapid determination of free proline for water-stress studies.Plant and Soil.39,205-207.

[22]. Cilas, C., Lanaud, C., Paulin, D., Nyasse, S., Ngoran, J.A., Kebe, B.I., Ducamp, M., Flamant, M.H., Risteruci, A.M., Pieretti, Saunigo, O., Thevenon, J.M., Despraux, D.(1998). La résistance à la pourriture des cabosses due à Phytophtora spp. Recherche des composantes de la résistance. Plantation, Recherche, Développement 5,441-445.

[23]. Djocgoue, P.F., Boudjeko, T., Nankeu, D.J., Efombagn, M.I.B., Nyasse, S., Omokolo, D.N. (2006). Comparative assessment of the resistance of Cocoa (Theobroma cacao L.) progenies from SNK10 x SNK413; ICS84 x ICS95 to Phytophthora megakarya in Cameroon by measuring size of necrotic lesion along the midrib. Plant Pathology Journal.5(3),329-335.

[24]. Ondobo, M.L., Effa, O.P., Djocgoue, P.F., Manga, N.J., Boudjeko, T., Omokolo, N.D. (2014). Phenolic content and heritability of resistance in four hybrid populations of Theobroma cacao L. after Leaves inoculation with Phytophthora megakarya Bras. andGrif.. International Journal of Biological and Chemical Sciences.8, 17-30.

[25]. Tahi, G.M., Kebe, B.I., N'Goran, J.A.K., Sangare, A., Mondeil, F., Cilas, C., Eskes, A.B. (2006). Expected selection efficiency for resistance to cacao pod rot (Phytophthorapalmivora) comparing leaf disc inoculations with field observations. Euphytica. 149: 3544.

[26]. Koc, E., Ustun,A.S.(2012). Influence of PhytophthoracapsiciL. inoculation on disease severity, necrosis length, peroxidase and catalase activity, and phenolic content of resistant and susceptible pepper (Capsicum annuumL.) plants. Turkish Journal of Biology.36: 357-371.

[27]. Nyadanu,D., Akromah,R., Adomako,B., Dzahini-Obiatey,H., Akrofi,A.Y., Lowor,S.T.,Assuah,M.K.(2012). Breeding for Multiple Disease Resistance in Cocoa (Theobroma cacao L.).International Journal of Plant Breeding and Genetic.6, 182-194.

[28]. Mpicka, J. (2009). Inhibition de Phytophthora palmivora, agent de la pourriture brune des cabosses de cacaoyer en Côte d'Ivoire, par Trichodermasp.Science et nature.6, 49-62.

[29]. Tondje, P.R., Roberts, D.P., Bon, M.C., Widmer, T., Samuels, G.J., Ismaiel, A., Begoude, A.D., Tchana, T., Nyemb-Tshomb, E., Ndoumbe-Nkeng, M., Bateman, R., Fontem, D., Hebbar, K.P. (2007). Isolation and identification of mycoparasitic isolates of Trichoderma asperellumwith potential for suppression of black pod disease of cacao in Cameroon. Biological Control. 43, 202212.

[30]. Omokolo, N.D., Nankeu, D.J., Niemenak, N., Djocgoue, P.F. (2002). Analysis of amino acids and carbohydrates in the cortex of nine clones of Theobroma cacao L. in relation to their susceptibility to Phytophthora megakarya Bra.etGrif. Crop Protection.21, $395-402$.

[31]. Iwaro, A.D., Sreenivason, T.N., Umaharan, P.(1998). Phytophthoraresistance in cocoa (Theobroma cacao): Influence ofpod morphological characteristics. Plant Pathology.46, 557-565.

[32]. Surujdeo-Maharaj, S., Umaharan, P., Iwaro, A.D.(2001). A study of genotype isolate interaction in cacao (Theobroma cacao L.): resistance of cacao genotypes to isolates of Phytophthorapalmivora. Euphytica. 118, 295-303.

[33]. Simo, C., Djocgoue, P.F., Mbouobda, H.D., Effa, O.P., Boudjeko, T., Ndiang, Z.,Omokolo, N.D. 2014. Assessing relationship between phenolic compounds and resistance to Phytophthoramegakarya using two cocoa (Theobroma cacao) families. African Journal of Biotechnology.13(9), 2956-2965.

[34]. Mbouobda, H.D., Fotso, Djocgoue, P.F., Omokolo, N.D., El HI.,Boudjeko,T.(2010). Benzo - (1,2,3) -Thiadiazole- 7 -carbothioc Smethyl ester (BTH) stimulates defense reactions in Xanthosomasagittifolium. Phytoparasitica. 38, 71-79.

[35]. Kodama, O., Miyakawa, J., Akatsuka, T., Kiyosawa, S.(1992). Sakuranetin, a flavanone phytoalexin from ultraviolet irradiated rice leaves. Phytochemistry. 31, 3807-3809.

[36]. Kodama, O.,Miyakawa, J., Akatsuka, T.Kiyosawa, S.(1992). Sakuranetin, a flavanone phytoalexin from ultraviolet irradiated rice leaves. Phytochemistry. 31, 3807-3809.

[37]. Djocgoue, P.F., Mbouobda, H.D., Boudjeko, T., Effa, O.P.,Omokolo,N.D. (2011). Aminoacids, carbohydrates and heritability of resistance in the Theobroma cacao/Phythophthora megakarya interaction. PhytopathologiaMediterraneae,50, 370-383.

[38]. Graham, T.L., Kim,J.E., GrahamMY(1990). Role of constitutive isoflavoneconfugates in the accumulation of glyceollin in soybean infected with P. megasperma. Molecular and Plant Microbe Interactions.3, 157-166.

[39]. Starrat, A.N.,Lazarovits,G. (1996). Increases in free amino acid levels in tomato plants accompagning herbicide-induce disease resistance. Pesticide Biochemistry and Physiology.54, 230-240.

[40]. Nemec, S.(1995). Stress-related compounds in xylem fluid of blight-disease citrus containing Fusarium solaninaphthazarintoxins and their effects on the host. Canadian Journal of Microbiology.41, 515-524.

\section{List of tables}

Table 1. Identification and origin of cocoa clones used in this study.

\begin{tabular}{|l|l|l|l|l|l|}
\hline \multicolumn{2}{|l|}{ Genotypes } & Origin & Collection & Group & Sensibility \\
\hline Clones & SNK 13 & Cameroon & Nkoemvone & Trinitario & Moderately tolerant \\
\hline & SNK 16 & & & & \\
\hline & SNK 413 & & & & \\
\hline & ICS 40 & Trinidad & $/$ & Trinitario & \\
\hline & UPA 134 & Ghana & Wacri & UA & Sensible \\
\hline & T 79/467 & & Tafo & & Tolerant \\
\hline & T 79/501 & & Tafo & & \\
\hline & SCA 12 & Ecuador & $/$ & & Moderately sensible \\
\hline
\end{tabular}


Virulence Test Of Some Phytophthora Megakarya Isolates On Cocoa (Theobroma Cacao L.)...

\begin{tabular}{|c|c|c|c|c|c|}
\hline \multirow{8}{*}{ Hybrids } & SCA $12 \times$ SNK 16 & Cameroon & Mengang & $\mathrm{UA} \times \mathrm{T}$ & Unknown \\
\hline & SNK $16 \times$ SCA 12 & & & $\mathrm{~T} \times \mathrm{UA}$ & \\
\hline & $\mathrm{T} 79 / 501 \times \mathrm{SNK} 413$ & & & & \\
\hline & SNK 413× T 79/501 & & & & \\
\hline & UPA $134 \times$ ICS 40 & & & & \\
\hline & ICS $40 \times$ UPA 134 & & & & \\
\hline & T 79/467 × SNK 13 & & & & \\
\hline & SNK $13 \times$ T 79/467 & & & & \\
\hline
\end{tabular}

$\mathrm{SNK}=$ selection Nkoemvone; ICS= Imperial college selection; UPA= Upper amazon; $\mathrm{T}=\mathrm{Tafo} ; \mathrm{SCA}=\mathrm{Scavina}$. Trinitario=T; Forastero=F; UA=Upper Amazon Forastero, LA=Lower Amazon Forastero

(Blaha and Lotode, 1976), and (Ondobo et al. 2014).

Table 2. Necrotic area $\left(\mathrm{cm}^{2}\right)$ recorded from the inoculation of $P$. megakarya-Bakoa isolate on eight hybrids ofT. cacao.

\begin{tabular}{|c|c|c|c|}
\hline & Bakoa & & \\
\hline Hybrids & Day 2 & Day 4 & Day 6 \\
\hline SNK 413×T 79/501 & $5.51 \pm 0.29 \mathbf{a}$ & $7.27 \pm 0.14 \mathbf{a}$ & $15.40 \pm 0.02 \mathbf{a}$ \\
\hline T 79/501×SNK 413 & $12.18 \pm 0.13 \mathrm{~cd}$ & $19.06 \pm 0.71 \mathbf{c}$ & $20.37 \pm 0.77 \mathbf{b}$ \\
\hline SNK 13×T 79/467 & $8.66 \pm 0.22 \mathbf{b}$ & $12.03 \pm 0.91 \mathbf{b}$ & $50.54 \pm 0.25 \mathrm{c}$ \\
\hline T 79/467×SNK 13 & $16.74 \pm 0.60 \mathrm{de}$ & $28.31 \pm 0.96 \mathbf{e}$ & $83.22 \pm 0.23 \mathbf{d}$ \\
\hline SNK 16×SCA 12 & $15.27 \pm 0.16$ de & $22.04 \pm 0.56 \mathrm{~cd}$ & $49.64 \pm 0.92 \mathbf{c}$ \\
\hline SCA $12 \times$ SNK 16 & $10.02 \pm 0.09 \mathbf{c}$ & $15.88 \pm 0.77$ bc & $46.20 \pm 0.09 \mathbf{c}$ \\
\hline ICS 40×UPA 134 & $6.70 \pm 0.39 \mathbf{a}$ & $11.98 \pm 0.68 \mathbf{b}$ & $24.68 \pm 0.23 \mathbf{b}$ \\
\hline UPA $134 \times$ ICS 40 & $11.46 \pm 0.62 \mathrm{c}$ & $26.41 \pm 0.22 \mathrm{de}$ & $78.97 \pm 0.05 \mathrm{~d}$ \\
\hline
\end{tabular}

Lowercase letters represent differences among days in the same genotypes. Mean symptom ratings within a day and followedby the same letter are not significantlydifferent according to the tukey test at 5\%

Table 3. Necrotic area recorded from the inoculation of P. megakarya-Lebdi isolate on eight hybrids of $\mathrm{T}$. cacao.

\begin{tabular}{|c|c|c|c|}
\hline \multirow[t]{2}{*}{ Hybrids } & \multicolumn{3}{|l|}{ Lebdi } \\
\hline & Day 2 & Day 4 & Day 6 \\
\hline SNK 413×T 79/501 & $2.25 \pm 0.24 \mathbf{a}$ & $3.59 \pm 0.63 \mathbf{a}$ & $9.75 \pm 0.24 \mathbf{a}$ \\
\hline T 79/501×SNK 413 & $4.81 \pm 0.13 \mathbf{b}$ & $6.72 \pm 0.51 \mathbf{b}$ & $19.66 \pm 0.44 \mathbf{e}$ \\
\hline SNK 13×T 79/467 & $7.63 \pm 0.07 \mathbf{c}$ & $8.30 \pm 0.76 \mathbf{b c}$ & $23.23 \pm 0.67 \mathbf{c}$ \\
\hline $\mathrm{T} 79 / 467 \times \mathrm{SNK} 13$ & $7.74 \pm 0.34 \mathbf{c}$ & $9.48 \pm 0.55 \mathrm{c}$ & $21.44 \pm 0.72$ c \\
\hline SNK 16×SCA 12 & $6.27 \pm 0.53$ bc & $9.75 \pm 0.16 \mathbf{c}$ & $17.50 \pm 0.61 \mathbf{b}$ \\
\hline SCA $12 \times$ SNK 16 & $5.92 \pm 0.86 \mathbf{b}$ & $8.92 \pm 0.91$ bc & $16.37 \pm 0.19 \mathbf{b}$ \\
\hline ICS 40×UPA 134 & $4.71 \pm 0.91 \mathbf{b}$ & $7.57 \pm 0.69 \mathbf{b}$ & $22.00 \pm 0.68 \mathbf{c}$ \\
\hline UPA $134 \times$ ICS 40 & $8.05 \pm 0.12 \mathrm{~cd}$ & $10.45 \pm 0.15 \mathrm{~cd}$ & $28.45 \pm 0.70 \mathrm{~d}$ \\
\hline
\end{tabular}

Lowercase letters represent differences among days in the same genotypes. Mean symptom ratings within a day and followed by the same letter are not significantlydifferent according to the tukey test at $5 \%$

Table 4. Necrotic area recorded from the inoculation of P. megakarya-Le4 isolate on eight hybrids of T. cacao.

\begin{tabular}{|c|c|c|c|}
\hline \multirow[t]{2}{*}{ Hybrids } & \multicolumn{3}{|l|}{ Le4 } \\
\hline & Day 2 & Day 4 & Day 6 \\
\hline SNK 413×T 79/501 & $1.52 \pm 0.51 \mathbf{a}$ & $6.86 \pm 0.26 \mathbf{a}$ & $13.49 \pm 0.23 \mathbf{a}$ \\
\hline T 79/501×SNK 413 & $4.22 \pm 0.19 \mathbf{b}$ & $6.96 \pm 0.89 \mathbf{a}$ & $19.00 \pm 0.09 \mathbf{c}$ \\
\hline SNK 13×T 79/467 & $3.08 \pm 0.74 \mathbf{b}$ & $7.88 \pm 0.31 \mathbf{a b}$ & $13.59 \pm 0.78 \mathbf{a}$ \\
\hline T 79/467×SNK 13 & $9.01 \pm 0.60 \mathrm{~d}$ & $14.15 \pm 0.50 \mathbf{c}$ & $21.92 \pm 0.38 \mathbf{d}$ \\
\hline SNK $16 \times$ SCA 12 & $7.82 \pm 0.63 \mathbf{c}$ & $9.47 \pm 0.60 \mathbf{b}$ & $16.33 \pm 0.47 \mathbf{b}$ \\
\hline SCA $12 \times$ SNK 16 & $2.90 \pm 0.39 \mathbf{a}$ & $5.97 \pm 0.10 \mathbf{a}$ & $12.59 \pm 0.86 \mathbf{a}$ \\
\hline ICS $40 \times$ UPA 134 & $5.46 \pm 0.11$ bc & $8.45 \pm 0.94 \mathbf{a b}$ & $14.90 \pm 0.45 \mathrm{ab}$ \\
\hline UPA $134 \times$ ICS 40 & $5.47 \pm 0.22$ bc & $9.28 \pm 0.99 \mathbf{b}$ & $13.59 \pm 0.02 \mathbf{a}$ \\
\hline
\end{tabular}

Lowercase letters represent differences among days in the same genotypes. Mean symptom ratings within a day and followed by the same letter are not significantlydifferent according to the tukey test at $5 \%$ 
Table 5.Spearman's correlations between the different parameters studied.

*. Correlation is significant at the 0.05 level

\begin{tabular}{|l|l|l|l|l|l|}
\hline SNK 413 $\times$ T 79/501 & Necrosis & PPT & Carbohydrates & Proline & Amino acids \\
\hline Necrosis & 1 & & & & \\
\hline PPT & $-0,881^{*}$ & 1 & & & \\
\hline Carbohydrates & $0,771^{* *}$ & $-0,857^{*}$ & 1 & & \\
\hline Proline & $-0,903^{*}$ & 0,805 & $-0,991^{* *}$ & 1 & \\
\hline Aminoacids & $-0,912^{*}$ & 0,841 & $-0,815^{*}$ & 0,753 & 1 \\
\hline T 79/467 $\times$ SNK 13 & & & & & \\
\hline Necrosis & 1 & & & & \\
\hline PPT & $-0,429$ & 1 & & & \\
\hline Carbohydrates & $0,829^{*}$ & $-0,486$ & 1 & & \\
\hline Proline & $-0,426$ & $0,952^{* *}$ & $-0,486$ & 1 & \\
\hline Aminoacids & $-0,468$ & $0,943^{* *}$ & $-0,513$ & $0,943^{* *}$ & 1 \\
\hline
\end{tabular}

**. Correlation is significant at the 0.01 level

\section{List of figures}

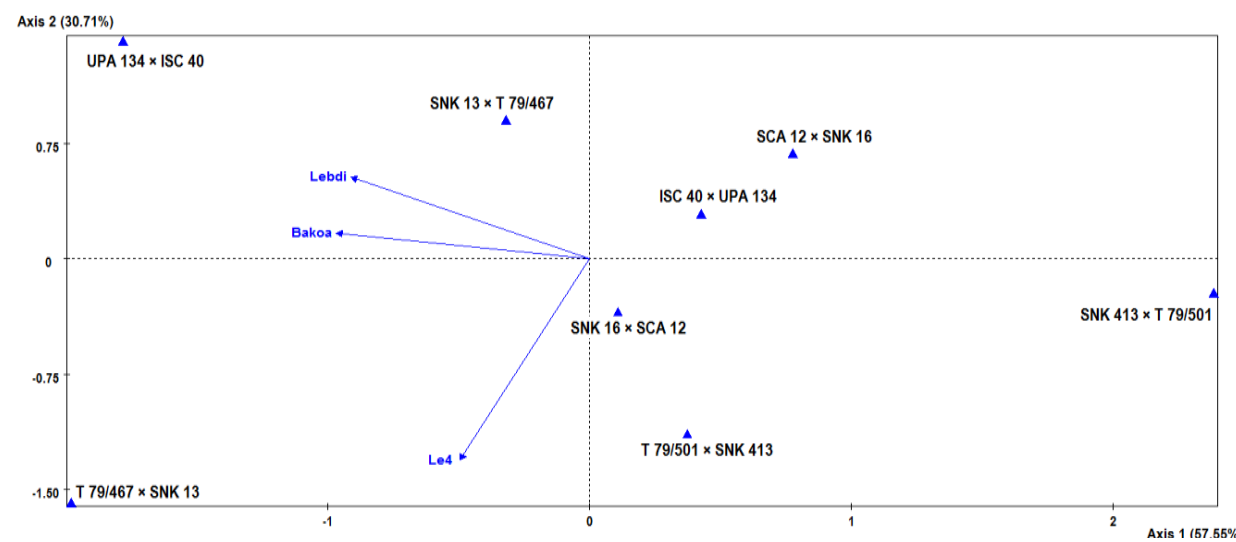

Fig.1. Loading plot of the first two axis based on infection of three P. megakarya isolates (Bakoa, Lebdi and Le4) on cocoa pods of different genotypes.

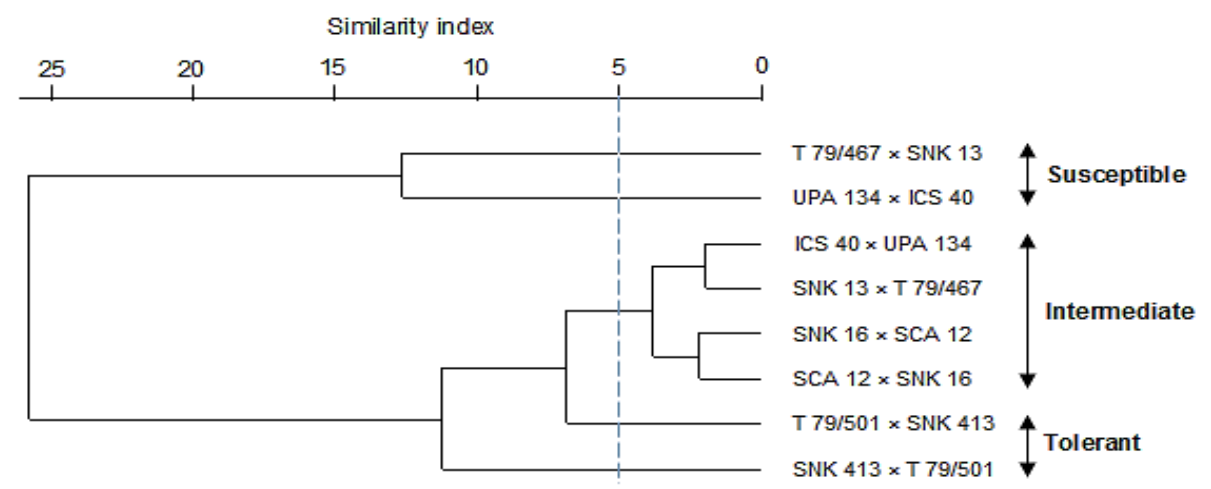

Fig. 2.Dendrogram of eight genotypes of T. cacao based on necrotic area after infection of three P. megakarya isolates (Bakoa, Lebdi and Le4).

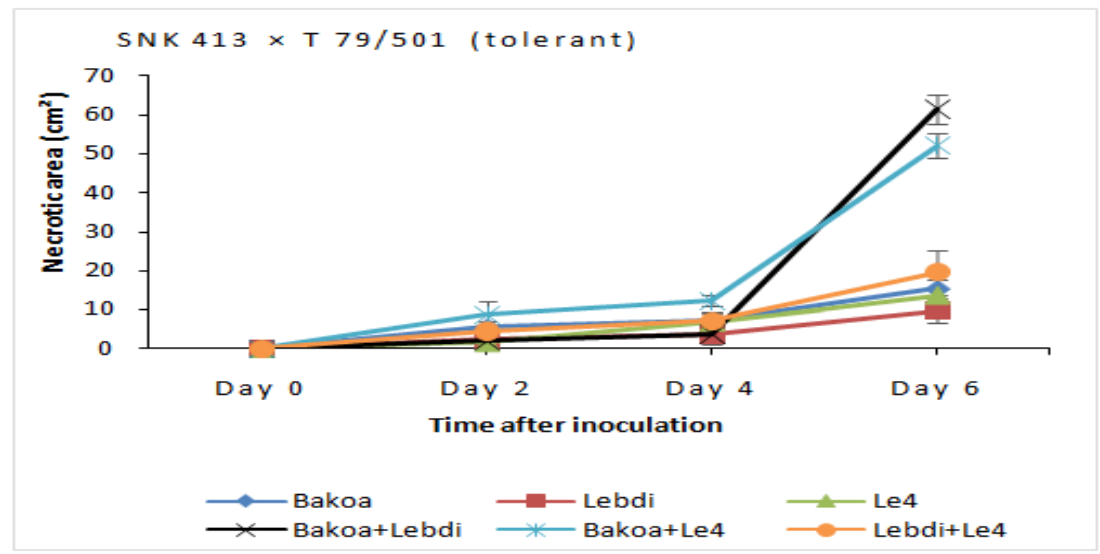




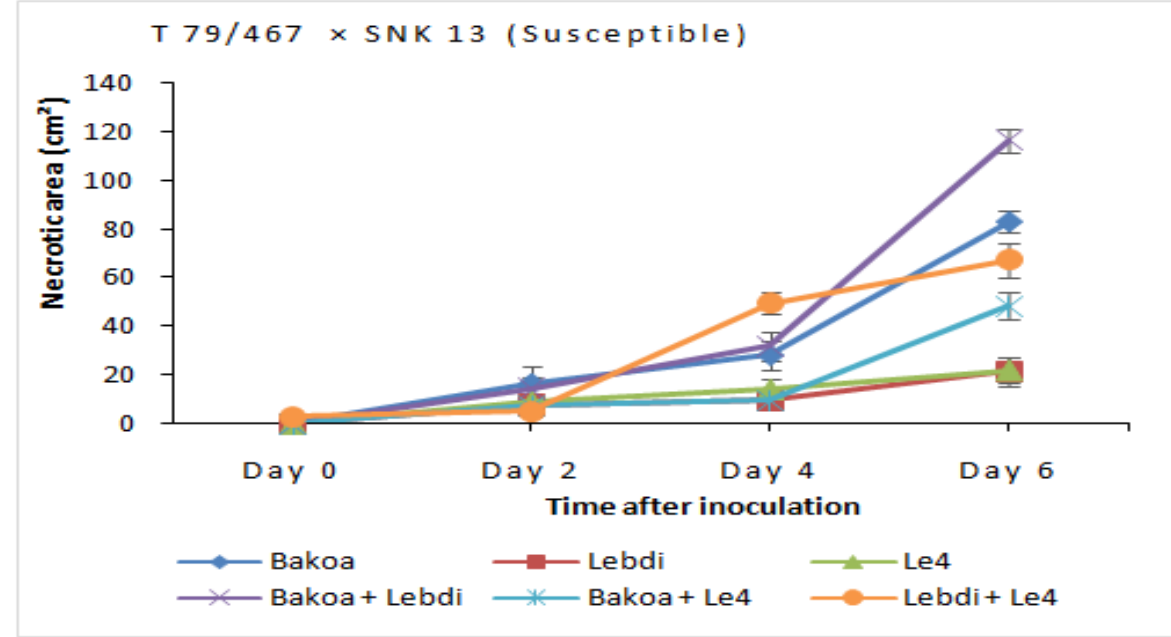

Fig. 3.Evolution of virulence level of $P$. megakarya isolates (Bakoa, Lebdi and Le4) and their three combinations (Bakoa+Lebdi, Bakoa+Le4 and Lebdi+Le4) on two genotypes [SNK413 x T79/501 (tolerant) and T79/467x SNK13 (susceptible)] after inoculation.

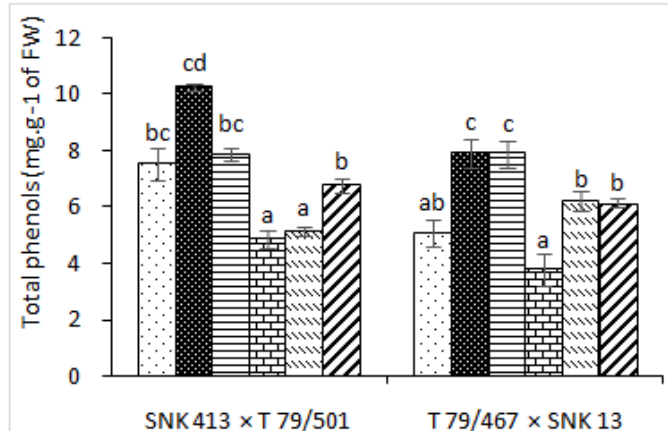

(A)

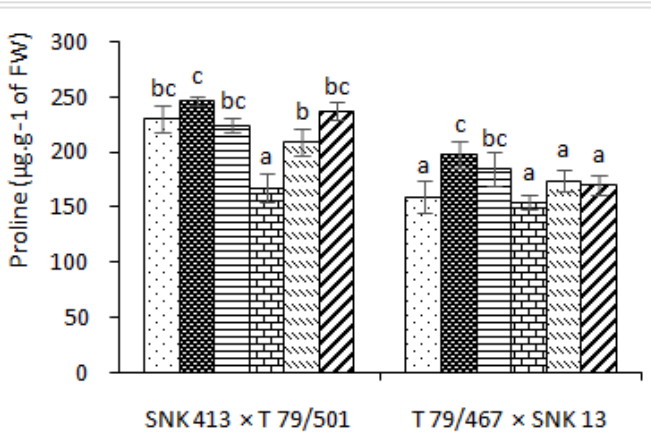

(C)
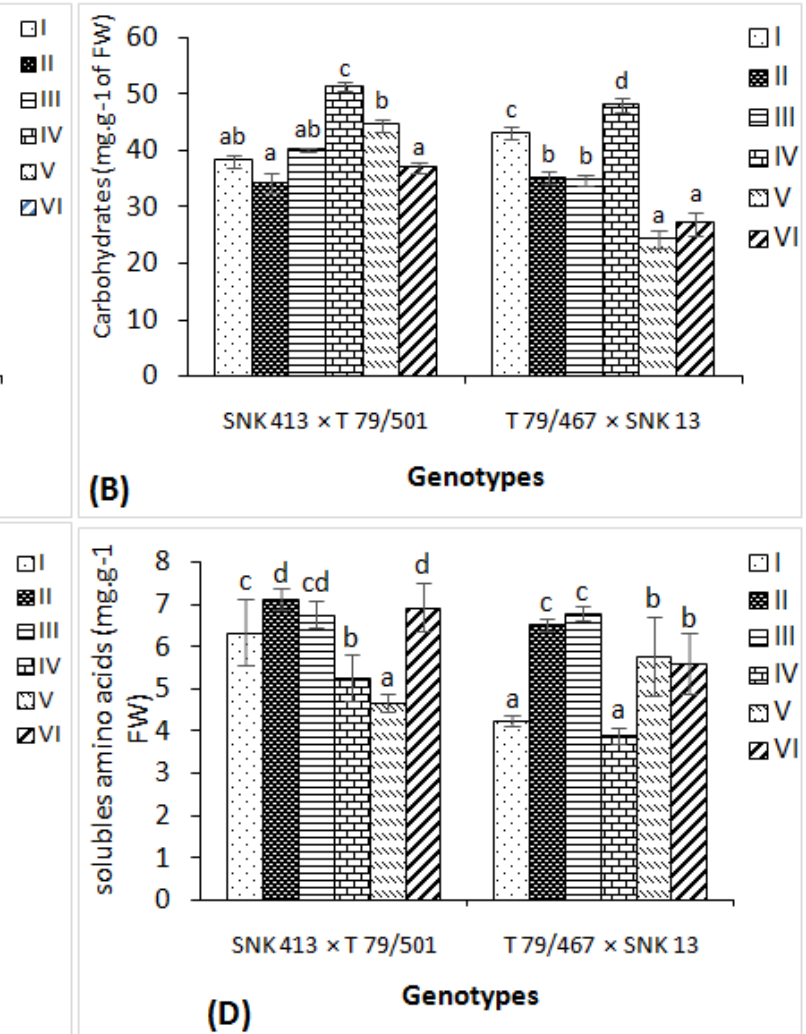

Fig. 4. Variation of some biochemical markers following infection of cocoa pods. (A): Total polyphenols; (B): Carbohydrates; (C): Proline; (D): Soluble amino acids. I: P. megakarya-Bakoa isolate, II: P. megakarya-Lebdi isolate, III: P. megakarya-Le4 isolate, IV: P. megakarya-Bakoa + Lebdi isolates, V: P. megakarya-Bakoa + Le4 isolates, VI: P. megakarya-Lebdi + Le4 isolates 